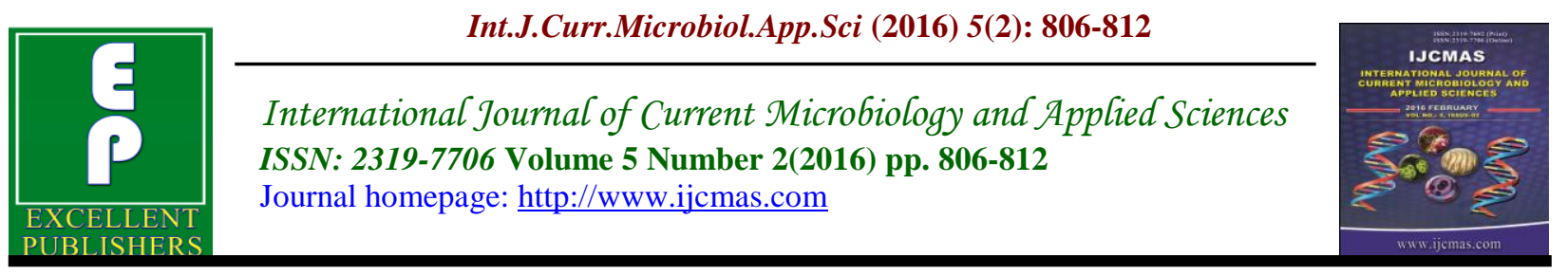

Original Research Article

doi: http://dx.doi.org/10.20546/ijcmas.2016.502.092

\title{
Decomposition Pattern in Pinus longifolia Leaf Litter in Chandak Forest in the Presence of Cow Dung and Urea
}

\author{
Asha Tiwari, Smriti Rawat* and R. S. Adhikari \\ Department of Botany, Kumaun University, L.S.M.G.P.G.College, \\ Pithoragarh, Uttarakhand, India \\ *Corresponding author
}

Keywords

Pinus longifolia, Decomposiiton,

Litter,

Chandak Forest, Cow dung, Urea

Article Info

Accepted:

28 January 2016

Available Online:

10, February 2016

\section{A B S T R A C T}

The aim of present study was to determine the effect of cow dung and urea on the mass loss and decomposition percentage of Pinus longifolia leaf litter in the Chandak forest of Pithoragarh. Litter bags technique was used to determine their mass loss in the forest floor for one year at monthly intervals. Litter bags were collected from untreated controlled samples and treated with 1:1 cow dung treated litter and $05 \%$ urea treated samples are taken to the laboratory and then analyzed for their weight loss and decomposition percentage. The decomposition percent was found maximum in the month of September $(10.29 \%)$ in 1:1 cow dung, whereas the decomposition percentages was found $6.42 \%$ in $05 \%$ urea and $5.47 \%$ in control condition respectively in the month of August and September. The favorable climatic conditions enhanced the decomposition percentages.

\section{Introduction}

Pinus roxburghii Sarg. (syn. Pinus longifolia Roxb.) (Pinaceae), commonly known as chir pine, is a tall tree with a spreading crown found in the Himalayan from Kashmir to Bhutan, Afghanistan and in southern Indian hills (Shuaib et al., 2013). It starts its growth in dense tufts at the end of pine boughs. It is attached to its bough by a sheath or cap (Das and Ramakrishnan, 1985). Litter fall and litter decomposition are key processes in nutrient cycling of forest ecosystems.
The process "plant litter decomposition" is necessary for the recirculation of nutrients and a continued buildup of plant biomass as well as for the maintenance of food webs through the energy released by the degradation of organic compounds. The main process of decomposition is extremely complex and can be subdivided into a multitude of sub processes. Meentemeyer (1978) and later Berg et al. (1993) demonstrated a large-scale effect of climate on decomposition rate of newly shed plant 
litter. However, such an effect is not general to all litter species (Berg, et al., 2000) and not to all decomposition stages (Johansson, et al., 1995), but the changed substrate composition may dominate decomposition rates at least for some foliar litter species.

Most studies of litter decomposition have been performed in different forest ecosystems; little information is available on decay responses forests (Cleveland et al., 2006; McGroddy et al., 2004; Micks et al., 2004; Vitousek, 1998), especially in the forests of Himalaya (Mo et al., 2007). This relationship was observed by (Fogel and Cromack, 1977) and later developed (Johansson et al., 1995) to different climate situations. The objective of this study is to evaluate the litter decomposition in natural forests of Pinus roxburghii in Pithoragarh district of the eastern Uttarakhand. The emphasis will be put on the relationship between the processes of litter decomposition and atmospheric temperature including litter treatment with cow dung and urea.

\section{Materials and Methods}

\section{Study Area}

The study was conducted in pure Pine forest of Chandak at Pithoragarh District of Kumaon Himalayas at an altitude of 1600 . This area is situated between Lat. $29^{\circ} 27^{\prime} \mathrm{N}$. and $30^{\circ} 49^{\prime} \mathrm{N}$. and Long. $79^{\circ} 50^{\prime} \mathrm{E}$. and $81^{\circ}$ $3 \mathrm{E}$. Chandak forest regions is present on $6000 \mathrm{ft}(1.830 \mathrm{~m})$ altitude surrounded by 283 Hectare of pine forest (Fig-1).

\section{Litter Collection and Litter Treatment}

The pine litter (only fresh fallen leaf litter) was collected in the summer season (from April to June) and brought to the laboratory carefully on polythene bags. The collected needle were weighted and sampled for litter decomposition treatments. A total number of 108 bags filled with leaf litter (100 g each) in nylon mash (2mm). Out of 108 bags, 36 bags of leaf litter were mixed with $05 \%$ urea solution and another 36 bags mixed with 1:1 cow dung with litter and 36 bags used as a control. All 108 bags placed on the Pine forest floor for one year. In regular monthly interval 3 bags from each treated and controlled litter samples taken out and brought to the laboratory in the pollythene bags and washed carefully, oven dried at 80 ${ }^{\mathrm{o}} \mathrm{C}$ and weighted finally. The decomposition percentage was calculated by weight loss. The mean monthly temperature ranges from $4.2^{\circ} \mathrm{C}$ in January to $28.4^{\circ} \mathrm{C}$. the climatic data are shown in Fig-2.

\section{Results and Discussion}

The maximum decomposition or minimum remaining litter biomass was found in cow dung treated litter $45.95 \mathrm{~g}$, whereas the decomposed litter was found remaining $60.75 \mathrm{~g}$ in urea treated litter and $67.53 \mathrm{~g}$ in control condition (Table 1).Though mixing of the cow dung and the urea solution increased the decomposition and the remaining litter biomass was observed significant (significant $(\mathrm{p}<0.05)$ in different treatments, none of the treatment revealed full litter decomposition . Continuous decrease in litter biomass in every month revealed that the environmental conditions were in support of litter decomposition and the mixing of cow dung was much supported than other conditions.

The average decomposition percent was found $6.25 \%$ in the treatment with cow dung treated litter, whereas the decomposition percentages was found 4.05 $\%$ in urea treated and $3.21 \%$ in control condition . The decomposition percent was found maximum in the month of September 
$10.29 \%$ in cow dung treated, whereas the decomposition percentages was found 6.42 $\%$ in urea treated and $5.47 \%$ in control condition respectively in the month of August and September (Table -1). The overall decomposition rate was higher in the months of rainy season as compared to other seasons. The decomposition percent was found minimum in the month of December $2.10 \%$ in control i.e., natural condition, whereas the decomposition percent were $2.24 \%$ in urea treated and $2.32 \%$ in cow dung solutions, respectively in the month of December and June. The overall decomposition rate decreased in the autumn and summer seasons as compared to rainy seasons. The correlation between monthly decay percent and different treatments revealed that application of the urea and the cow dung solutions may increase the decomposition rates up to $65 \%$ and $66 \%$ respectively than the normal natural conditions 38\%.(Fig-4,5,6)

Table.1 Monthly Remaining Biomass and Decomposition Percentage in Different Treatments

\begin{tabular}{|c|c|c|c|c|c|c|c|}
\hline \multirow[b]{2}{*}{ Month } & \multirow{2}{*}{$\begin{array}{c}\text { Elapsed } \\
\text { day }\end{array}$} & \multicolumn{3}{|c|}{ Weight loss of leaf litter } & \multicolumn{3}{|c|}{ Decomposition \% of leaf litter } \\
\hline & & Control & Urea & $\begin{array}{l}\text { Cow } \\
\text { dung }\end{array}$ & Control & Urea & Cow dung \\
\hline July & 30 & 95.85 & 93.71 & 91.35 & 4.15 & 6.29 & 8.65 \\
\hline August & 60 & 91.75 & 87.70 & 82.87 & 4.27 & 6.42 & 9.28 \\
\hline September & 90 & 86.74 & 82.28 & 74.34 & 5.47 & 6.17 & 10.29 \\
\hline October & 120 & 83.08 & 77.18 & 68.15 & 4.21 & 6.20 & 8.32 \\
\hline November & 150 & 81.06 & 73.85 & 63.87 & 2.43 & 4.31 & 6.28 \\
\hline December & 180 & 79.36 & 72.20 & 60.47 & 2.10 & 2.24 & 5.32 \\
\hline January & 210 & 77.56 & 70.50 & 57.68 & 2.27 & 2.35 & 4.61 \\
\hline February & 240 & 75.71 & 68.85 & 55.77 & 2.38 & 2.34 & 3.33 \\
\hline March & 270 & 73.93 & 66.49 & 53.05 & 2.35 & 3.43 & 4.87 \\
\hline April & 300 & 71.46 & 64.30 & 50.21 & 3.34 & 3.28 & 5.35 \\
\hline May & 330 & 69.11 & 62.19 & 47.04 & 3.29 & 3.28 & 6.32 \\
\hline June & 360 & 67.53 & 60.75 & 45.95 & 2.29 & 2.32 & 2.32 \\
\hline
\end{tabular}

Fig.1 Location of the Study Area

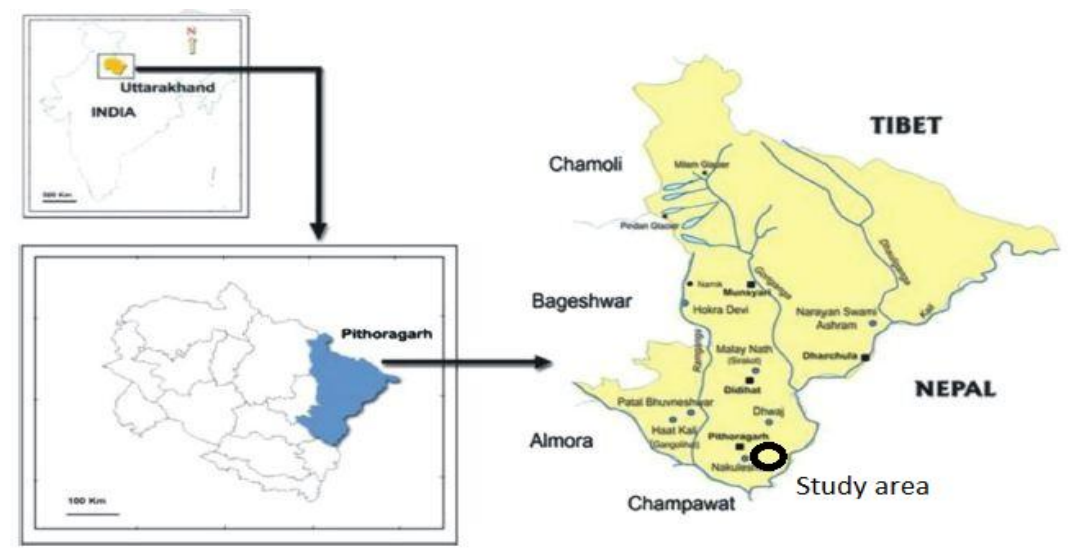


Fig.2 Average Annual Temperature, Humidity and Rainfall of the Study Area

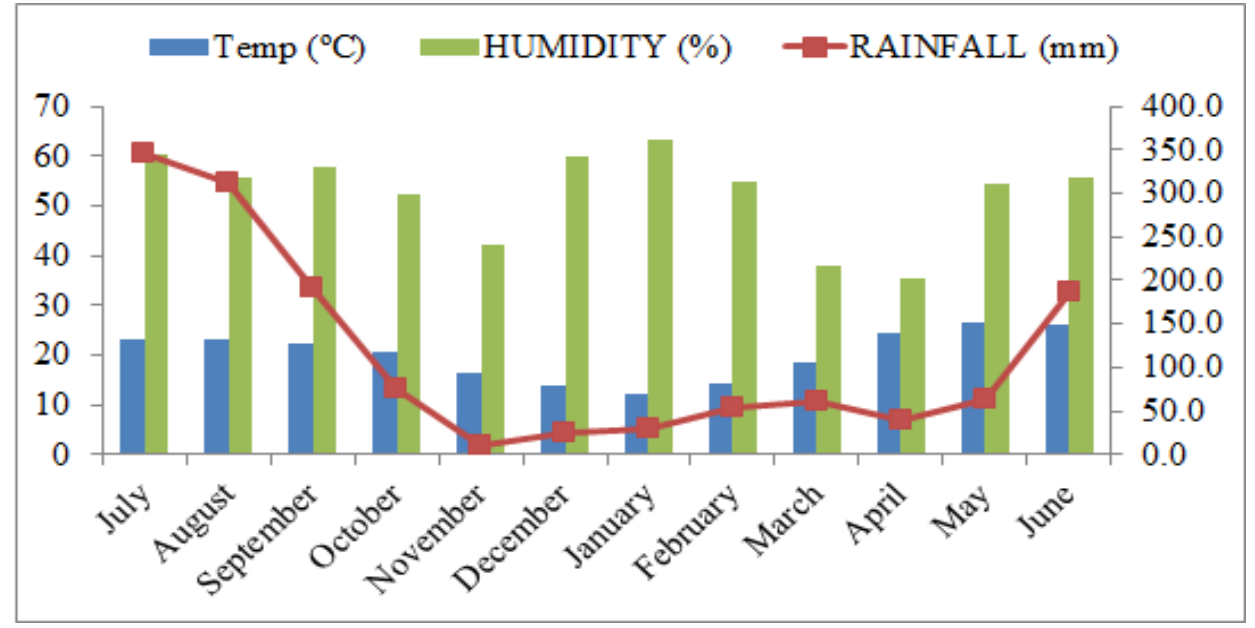

Fig.3 Litter Decomposition (\%) in Different Treatments

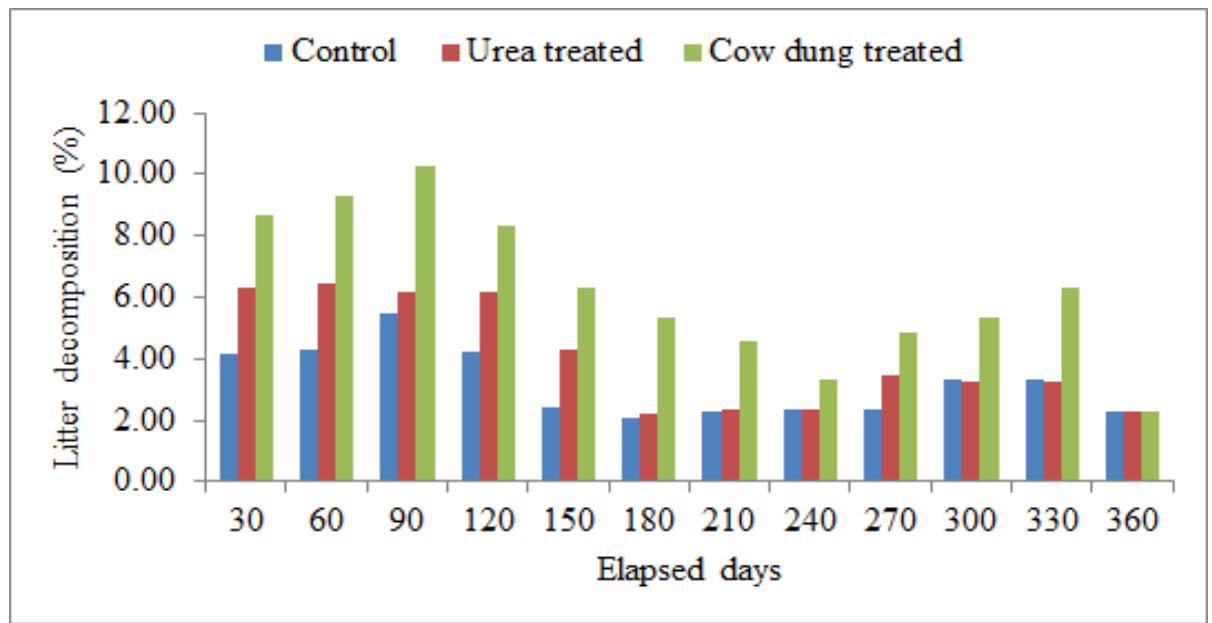

Fig.4 Litter Decomposition Percentage in Control Treatment

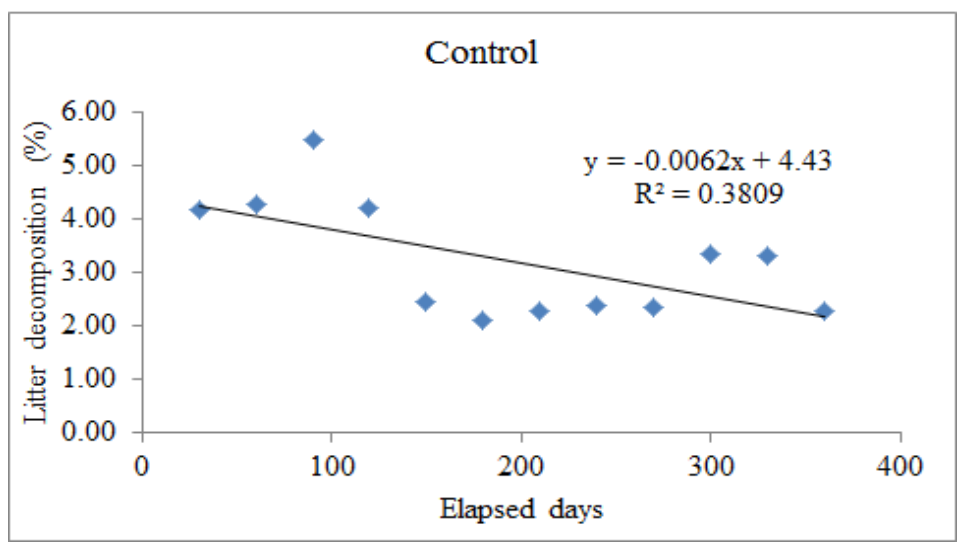


Fig.5 Litter Decomposition of Urea Treated Litter

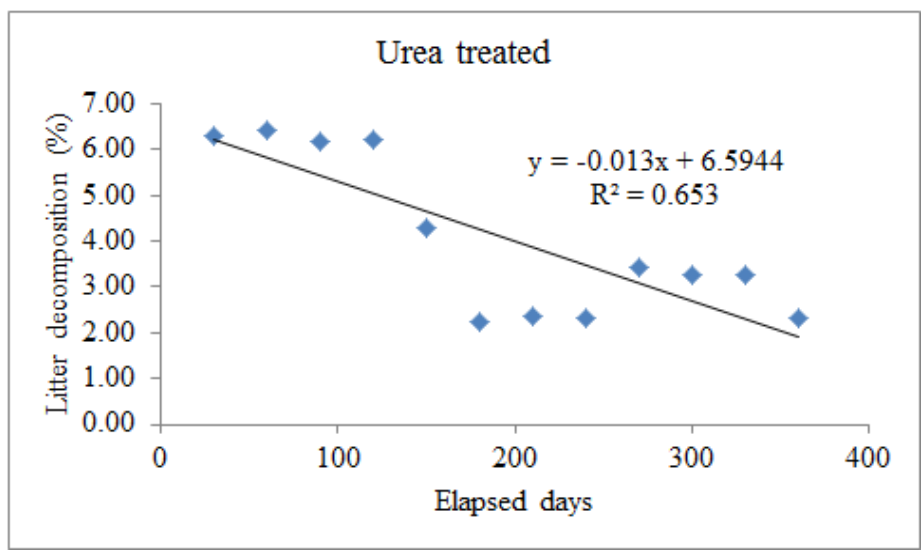

Fig.6 Litter Decomposition Cow Dung Treated Litter

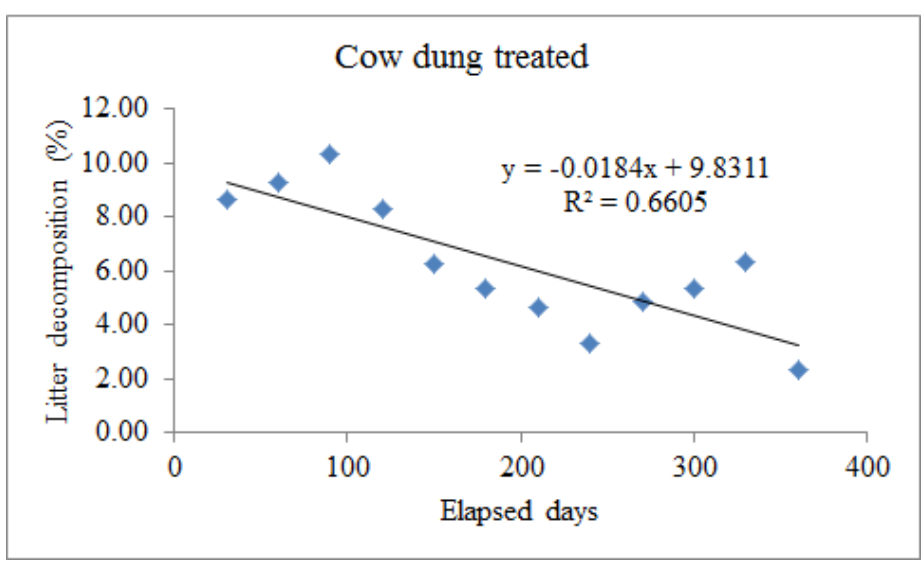

Present results revealed application of 5\% urea solution and the cow dung treatment increased the average decomposition percent whereas the decomposition percentages was lower in control condition. This indicates that cow dung gives suitable surface for the growth of microbes like fungus and insects, and they are responsible for the decomposition of litter. The earlier works done by Xiaoming and Suzuki (2004) revealed effects of urea treatment on litter decomposition and in urea-treated plots, the decomposition rate of leaves was greater than that of control. Bhattacharyya et al., 2005 found that the treatments consisted of control, no input; cow manure, Urea and Fertilizer single dung and urea were integrated and compared to their single applications. Benitez et al. (1999) have reported that decomposition of organic materials by application of cow dung accelerates the mineralization process of the substrate.

Climatic conditions also play crucial role on the decomposition of the decomposing matter. Table-1 shows the effect of temperature and rainfall during different period of the year were different decomposition rate. High decomposing percentage shows high temperature, rainfall and high humidity which may also resulted into high microbial activity and vice versa. (Pandey and Singh, 1982; Bahuguna et al., 
1990). The decomposition percentage were maximum in the months of August and September, in the rainy seasons due to high humidity the microbial activity was highest due to the favorable effect of soil moisture on the activates of decomposer.

In conclusion, the application of Urea and cow dung increased the decomposition rate and percentage than control treatment whereas the decomposition rate and percentage was found maximum in cow dung treatment.

\section{References}

Bahuguna, V.K., Negi, J.D.S., Joshi, S.R. and Naithani, K.C. 1990. Leaf litter decomposition and nutrient release in Shorea rubusta and Eucalyptus camaldulensis plantation. Indian Forester, 116(2) : 103-114.

Benitez, E., Nogales, R., Elvira, C., Masciandaro, G. and Ceccanti, B. 1999. Enzyme activities as indicators of the stabilization of sewage sludge composting with Eisenia foetida. Bioresour Technol 67:297-303.

Berg, B., M. P. Berg, Bottner, P. 1993. "Litter mass loss rates in pine forests of Europe and Eastern United States: some relationships with climate and litter quality," Biogeochemistry, vol. 20 , no. 3, pp. 127-153.

Berg, B., M.-B. Johansson, and Meentemeyer, V. 2000. "Litter decomposition in a transect of Norway spruce forests: substrate quality and climate control," Canadian Journal of Forest Research, vol. 30, no. 7, pp. 1136-1147.

Bhattacharyya, P., Chakrabarti, K. and Chakraborty, A. 2005. Microbial biomass and enzyme activities in submerged rice soil amended with municipal solid waste compost and decomposed cow manure. Chemosphere, 60(3), 310-318.

Cleveland C.C., Reed S.C., and Townsend A.R., 2006. Nutrient regulation of organic matter decomposition in a tropical rain forest. Ecology 87:492503.

Das, A. K., \&Ramakrishnan, P. S. 1985. Litter dynamics in khasi pine (Pinus kesiyaRoyle ex Gordon) of northeastern India. Forest Ecology and Management, 10(1), 135-153.

Fogel, R. and Cromack,K. 1977 ."Effect of habitat and substrate quality on Douglas fir litter decomposition in western Oregon," Canadian Journal of Botany, vol. 55, pp. 1632-1640.

Johansson, M. B. , B. Berg, and Meentemeyer,V. 1995 "Litter massloss rates in late stages of decomposition in a climatic transect of pine forests. Long-term decomposition in a Scots pine forest. IX," Canadian Journal of Botany, vol. 73, no. 10, pp. 1509-1521.

McGroddy M.E., Silver W.L., and Cosme de Oliveira J.R., 2004. The effect of phosphorus availability on decomposition dynamics in a seasonal lowland Amazonian forest. Ecosystems 7: 172-179.

Meentemeyer, V. 1978. Macroclimate and lignin control of litter decomposition rates. Ecology 59: 465-475.

Micks P., Down M.R., Magill A.H., Nadelhoffer K.J., and Aber J.D., 2004. Decomposition litter as a sink for $15 \mathrm{~N}-$ enriched additions to an oak forest and a red pine plantation. For. Ecol. Manage. 196: 71-87.

Mo J.M., Brown S., Xue J.H., Fang Y.T., Li Z.A., Li D.J., and Dong S.F., 2007. Response of nutrient dynamics of decomposing pine (Pinus massoniana) needles to simulated $\mathrm{N}$ deposition in a 
disturbed and rehabilitated forest in tropical China. Ecol. Res. 22: 649-658.

Pandey, U. and Singh, J.S. 1982. Leaf litter decomposition in oak conifer forest in Himalaya the effect of climate and chemical composition. Forestry, 55(1):47-59.

Vitousek P.M., 1998. Foliar and litter nutrients, nutrient resorption, and decomposition in Hawaiian Metrosiderospolymorpha. Ecosystems 1: 401-407.

Xiaoming, H., and Suzuki, A. 2004. Effects of urea treatment on litter decomposition in Pasania edulis forest soil. J. Wood Sci. 50(3): 266-270.

\section{How to cite this article:}

Asha Tiwari, Smriti Rawat and Adhikari, R. S. 2016. Decomposition Pattern in Pinus longifolia Leaf Litter in Chandak Forest in the Presence of Cow Dung and Urea. Int.J.Curr.Microbiol.App.Sci.5(2): 806-812. doi: http://dx.doi.org/10.20546/ijcmas.2016.502.092 